\title{
Variation in the isotopic composition of striped weakfish Cynoscion guatucupa of the Southwest Atlantic Ocean in response to dietary shifts
}

\author{
M. N. Paso Viola ${ }^{a, b *}$, L. Riccialdelli ${ }^{b}$, A. Jaureguizar ${ }^{c}$, H. O. Panarello and H. L. Cappozzo $^{a, e}$ \\ aLaboratorio de Ecología, Comportamiento y Mamíferos Marinos, Museo Argentino de Ciencias Naturales "Bernardino \\ Rivadavia" - MACN-CONICET, Av. Ángel Gallardo 470, C1405DJR, Ciudad Autónoma de Buenos Aires, Argentina

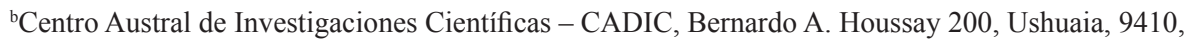 \\ Tierra del Fuego, Argentina \\ ${ }^{\mathrm{c}}$ Comisión de Investigaciones Científicas - PB/CIC, Instituto de Investigación y Desarrollo Pesquero - INIDEP, \\ Paso Victoria Ocampo 1, Mar del Plata, Argentina \\ dInstituto de Geocronología y Geología Isotópica - INGEIS, Pabellón INGEIS, Ciudad Universitaria, \\ CABA C1428EHA, Argentina

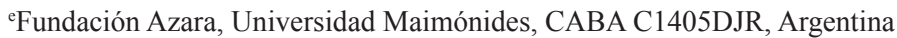 \\ *e-mail:npasoviola@gmail.com
}

Received: January 26, 2016 - Accepted: October 18, 2016 - Distributed: May 31, 2018

(With 6 figures)

\begin{abstract}
The aim of this study was to analyze the isotopic composition in muscle of striped weakfish Cynoscion guatucupa from Southwest Atlantic Ocean in order to evaluate a possible variation in $\delta^{13} \mathrm{C}$ and $\delta^{15} \mathrm{~N}$ in response to dietary shifts that occur as animals grow. We also explored for isotopic evidence of differences between sample locations. The results showed an agreement between isotope analysis and previous conventional studies. Differences in the isotope composition between sampling location were not observed. A positive relation exists between isotope values and total body length of the animals. The Cluster analysis defined three groups of size classes, validated by the MDS. Differences in the relative consumption of prey species in each size class were also observed performing isotope mixing models (SIAR). Variation in $\delta^{15} \mathrm{~N}$ among size classes would be associated with the consumption of a different type of prey as animals grow. Small striped weakfish feed on small crustaceans and progressively increase their consumption of fish (anchovy, Engraulis anchoita), increasing by this way their isotope values. On the other hand, differences in $\delta^{13} \mathrm{C}$ values seemed to be related to age-class specific spatial distribution patterns. Therefore, large and small striped weakfish remain specialized but feeding on different prey at different trophic levels. These results contribute to the study of the diet of striped weakfish, improve the isotopic ecology models and highlight on the importance of accounting for variation in the isotopic composition in response to dietary shifts with the size of one of the most important fishery resources in the region.
\end{abstract}

Keywords: Cynoscion guatucupa, stable isotopes, diet, ontogenetic shifts, Southwest Atlantic Coastal Ecosystem.

\section{Variação na composição isotópica do Cynoscion guatucupa no Oceano Atlântico Sul}

\section{Resumo}

O objetivo deste estudo foi analisar a composição isotópica no músculo de Cynoscion guatucupa no Oceano Atlântico Sul Ocidental, a fim de avaliar uma possível variação de $\delta^{13} \mathrm{C}$ e $\delta^{15} \mathrm{~N}$ como resposta às mudanças ontogenéticas na dieta. Foram também exploradas evidências isotópicas de diferenças entre os locais de amostragem. Os resultados mostraram uma concordância entre a análise de isótopos e os estudos convencionais prévios. Diferenças na composição isotópica entre locais de amostragem não foram observadas. Uma relação positiva existe entre valores isotópicos e comprimento total dos animais. A análise de cluster definiu três grupos de classes de tamanho, validados pelo MDS. Foram também observadas, através de modelos isotópicos mistos (SIAR), diferenças no consumo relativo de espécies de presas para cada classe de tamanho. Variações em $\delta^{15} \mathrm{~N}$ entre as classes de tamanho estariam associadas ao consumo de diferentes tipos de presas ao longo do crescimento dos animais. Indivíduos pequenos alimentam-se de pequenos crustáceos e progressivamente aumentam seu consumo de peixes (Engraulis anchoita), aumentando assim os seus valores isotópicos. Por outro lado, as diferenças nos valores de $\delta^{13} \mathrm{C}$ parecem estar relacionadas com variações no padrão de distribuição espacial específico de cada 
classe idade. Desta maneira, tanto C. guatucupa grandes como pequenos permanecem especializados, porém alimentando-se de presas diferentes, em diferentes níveis tróficos e em diferentes áreas. Estes resultados contribuem para o estudo da dieta de C. guatucupa, melhoram os modelos de ecologia isotópica e ressaltam a importância de se considerar a variação na composição isotópica na resposta às mudanças de dieta relacionadas ao tamanho de um dos principais recursos pesqueiros da região.

Palavras-chave: Cynoscion guatucupa, isótopos estáveis, dieta, mudanças ontogenéticas, Atlântico Sul Ocidental.

\section{Introduction}

The striped weakfish Cynoscion guatucupa (Cuvier 1830) inhabits coastal bottom waters from Río de Janeiro, Brazil $\left(22^{\circ} \mathrm{S}\right)$ to Chubut, Argentina ( $\left.43^{\circ} \mathrm{S}\right)$ (Haimovici, 1998; Cousseau and Perrotta, 2000) and is one of the most important coastal fishery resources of Argentina, Brazil and Uruguay (Haimovici, 1998; Jaureguizar et al., 2006; Ruarte and Aubone, 2008).

Within the Southwest Atlantic Coastal Ecosystem (SWACE, between $34^{\circ}$ and $41^{\circ} \mathrm{S}$ ) this species is captured by bottom trawlers in all seasons (Cordo, 1986). In the southern SWACE $\left(38^{\circ}-41^{\circ} \mathrm{S}\right)$ C. guatucupa has supported important commercial (Perrotta and Ruarte, 2009), recreational (57\% of catch in San Blas bay, Llompart et al., 2011) and artisanal fisheries since 1900 (Elias et al., 2011). This stock was severely depleted from 1995 to 2006 (Aubone et al., 2006), decreasing its yields of the artisanal fishing fleet in Bahía Blanca estuary, which finally collapsed between 2000 and 2004 (Lopez Cazorla et al., 2014). Moreover, this species is still an important prey of different species of marine predators (Suarez et al., 2005; Paso Viola et al., 2014).

The feeding habits of C. guatucupa in Argentinean waters has been assessed through conventional methodologies (stomach content analysis), in the Río de la Plata (Giberto, 2008) and Bahía Blanca estuaries (Lopez Cazorla, 1996; Sardiña and Lopez Cazorla, 2005), and in Buenos Aires coast (García, 2007), including Mar Chiquita Lagoon (Blasina et al., 2015). In southern Buenos Aires coast, diet studies determined this species feeds on crustaceans in its early stages and its diet shifts to fish, being the anchovy Engraulis anchoita Hubbs and Marini 1935 the dominant prey with the highest contribution to the diet (Sardiña and Lopez Cazorla, 2005; García, 2007). The importance of this pelagic fish in the diet of C. guatucupa may be due to its abundance in the area, representing also an important economic resource and supporting a directed fishery within the Argentinean continental shelf (Cousseau and Perrotta, 2000).

Due to that stomach content analysis has some inherent biases such as differential recovery rates, degradation or passage times of prey remains (Bowen, 2000), the use of stable isotope analysis is a helpful complementary tool to study trophic behavior and diet composition of many organisms (Phillips, 2001; Post, 2002). The fact that stomach content analysis only provides information on recently ingested prey and stable isotope analysis reflected diet assimilated over time (Newsome et al., 2009) reinforce the importance of using this complementary tools together. The success is based on the fact that stable isotope ratios (e.g. ${ }^{15} \mathrm{~N} /{ }^{14} \mathrm{~N},{ }^{13} \mathrm{C} /{ }^{12} \mathrm{C}$ ) of predators reflect those of their prey (Hobson and Clark, 1992). A difference of 2\%o - 5\%o in $\delta^{15} \mathrm{~N}$ values between predator and prey tissues may be measured, making it a reliable indicator of trophic level (Post, 2002; Michener and Kaufman, 2007). On the other hand, small differences of $\sim 0.5-1.0 \%$ o between predator and prey tissues are expected in $\delta^{13} \mathrm{C}$ values (Michener and Kaufman, 2007), being particularly valuable for estimating food sources and identifying animal movement patterns (Post, 2002).

For many aquatic organisms, such as fish, the size of potential prey increases with predator size since their diet is generally constrained by their morphometric characteristics such as the size of their jaws, among other factors (e.g. feeding behavior, prey availability) (Sheldon et al., 1977; Lundvall et al., 1999). Larger individuals occupy higher trophic levels as they increase the range of prey size consumed by adding larger prey to their diets (Scharf et al., 2000). Consequently, size-related dietary shifts may be prevalent in many fish species (Galvan et al., 2010; Davis et al., 2012). The stable isotope analyses provide an alternative technique to document size-related or ontogenetic diet shifts, as changes in diet composition generate differences in the trophic position and the ecological role occupied by $C$. guatucupa in the SWACE, information necessary to develop ecosystemic models for fishery management within an ecosystem approach.

Therefore, the aim of this study was to investigate intraspecific variation in the trophic habits such as size-related or ontogenetic diet shifts of C. guatucupa assessing the isotopic composition of the individuals from southern SWACE and to explore for evidence of isotopic differences between sample locations.

\section{Material and Methods}

\subsection{Study area and fish samples}

A total of 53 fish samples were collected in the Southwest South Atlantic Coastal Ecosystem SWACE, including the localities of Necochea (N), Claromecó (CLA), Monte Hermoso (MH) and Bahía Blanca (BB), places of artisanal fishery (Figure 1). Of them, 26 specimens of C. guatucupa were collected near Necochea during an oceanographic expedition on board the research vessel "Captain Oca Balda” OB-06/11 (National Institute of Fisheries Research and Development - INIDEP) and others 25 were obtained directly from artisanal fishermen in December 2010 and 


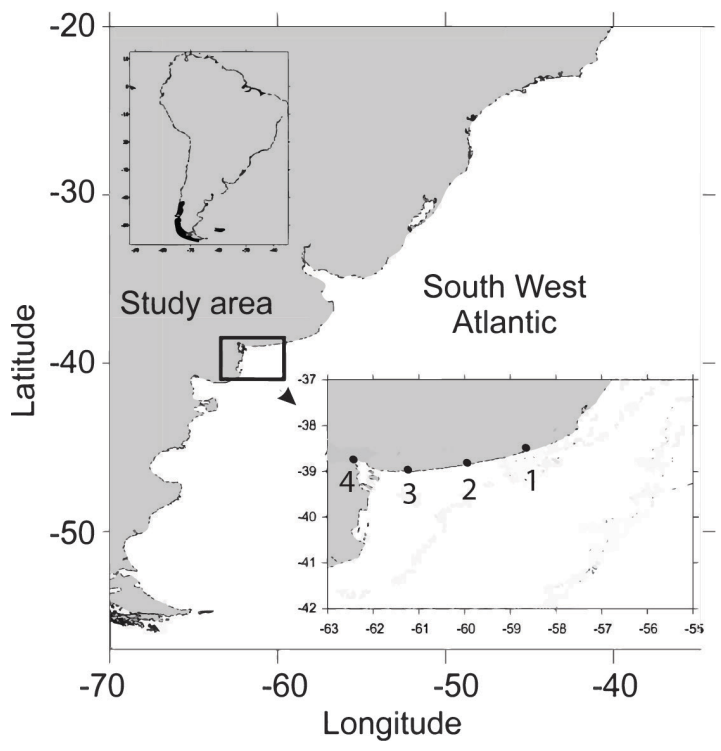

Figure 1. Study area in Southwest Atlantic Coastal Ecosystem (SWACE). Sampling location: (1) Necochea; (2) Claromecó; (3) Monte Hermoso y (4) Bahía Blanca with Bahía Blanca estuary.

February 2011. Additionally, two specimens of $E$. anchoita were collected in BB estuary during OB-06/11.

Range, mean \pm S.D of total body length (TL) and number ( $\mathrm{n}$ ) of the specimens from each sampling location were recorded, N: $9.0-32.3,19.3 \pm 7.2 \mathrm{~cm}, \mathrm{n}=36$; CLA: 29.5 - 34.0, $31.18 \pm 2.09, \mathrm{n}=4$; MH: $22.0-26.8$, $23.97 \pm 1.43, \mathrm{n}=11$. Since $C$. guatucupa individuals from SWACE reach their first maturity at $\sim 29.0 \mathrm{~cm}$ of TL (Cousseau et al., 1986; Macchi and Acha, 1998) and at 4 years of age (Vieira and Haimovici, 1997; Ruarte and Saez, 2008), the specimens collected for this study (9.0 - $34.0 \mathrm{~cm}$ of TL) corresponded mostly to juveniles up to 4 years $(78.4 \%)$.

\subsection{Stable isotope analysis}

A sample of dorsal muscle of each fish $(n=53)$ was stored at $-20^{\circ} \mathrm{C}$. Then, $\sim 0.1 \mathrm{~g}$ of each sample was dried in an oven at $60^{\circ} \mathrm{C}$ for $\sim 48$ hours. Lipids were removed by repeated rinsing with 2:1 chloroform:methanol solution. The resulting protein preparations were then rinsed several times with distilled water and dried at $60{ }^{\circ} \mathrm{C}$ for $\sim 24 \mathrm{~h}$. Lipids are depleted in $\delta^{13} \mathrm{C}$ in relation to proteins (Post et al., 2007; Logan et al., 2008), therefore lipid extraction was extremely important because of the large amount presented in fish muscle.

Dried samples $(~ 0.5$ to $0.6 \mathrm{mg})$ were weighed into tin capsules $(3 \mathrm{~mm} \times 5 \mathrm{~mm})$ and analyzed with a Carlo Erba Elemental Analyzer interfaced with a Thermo ConFlo IV to a Finnigan MAT Delta V isotope ratio mass spectrometer at the Instituto de Geología y Geocronologia Isotópica (INGEIS). Results were expressed in delta $(\delta)$ notation according to the Equation 1 (Coplen, 2011): $\delta^{13} \mathrm{C}$ or $\delta^{15} \mathrm{~N}=\left[\left(\mathrm{R}_{\text {sample }} * \mathrm{R}_{\text {standard }}{ }^{-1}\right)-1\right]$

where $\mathrm{R}_{\text {sample }}$ and $\mathrm{R}_{\text {standard }}$ are the ${ }^{13} \mathrm{C}:{ }^{12} \mathrm{C}$ or ${ }^{15} \mathrm{~N}:{ }^{14} \mathrm{~N}$ ratios of the sample and standard respectively. The standards were Vienna Pee Dee Belemnite limestone (VPDB) for carbon and atmospheric (AIR) $\mathrm{N}_{2}$ for nitrogen (Coplen et al., 1992). The units were expressed as parts per mil (\%o). Sample precision based on repeated measures of internal standards was $0.2 \%$ for both $\delta^{13} \mathrm{C}$ and $\delta^{15} \mathrm{~N}$.

\subsection{Data analysis}

Specimens were grouped by their isotopic similarity $\left(\delta^{13} \mathrm{C}\right.$ and $\left.\delta^{15} \mathrm{~N}\right)$ in size classes using statistical techniques, hierarchical Cluster Analysis (Euclidean distance, group average) and Multidimensional Scaling Analysis (MDS). The sizes of individuals were clustered in intervals of classes with amplitude of $0.50 \mathrm{~cm}$ of TL, and 0.25 and 0.75 were the class marks of the size interval. Clarke et al. (2008) suggested using a combination of SIMPROF with hierarchical cluster analysis to indicate which clusters have non-random structures.

The isotopic variability of $\delta^{13} \mathrm{C}$ and $\delta^{15} \mathrm{~N}$ regarding sampling location was tested performing One-way ANOVA and Tukey multiple comparisons. These differences were analyzed among the same size class and between those most distant locations of the sampling area ( $\mathrm{N}$ and $\mathrm{MH})$, separated by $\sim 250 \mathrm{~km}$ away from the coastline. It was not possible to compare between all sample locations because of the low number of individuals. One-way ANOVA and Tukey multiple comparisons were used to test whether significant differences were detected for isotope values between size classes. Then, the relationship between $\delta^{13} \mathrm{C}$ and $\delta^{15} \mathrm{~N}$ values with size (TL) was analyzed through the Pearson correlation coefficient $(r)$.

Shapiro-Wilks and Levene's tests were applied to assess data normality and homogeneity of variance, respectively. Statistical analyses were performed with the software InfoStat.Ink (Di Rienzo et al., 2011). For all calculation, significance was tested at $\alpha=0.05$ level.

The relative contribution of different prey taxa to the diet of C. guatucupa, discriminated by size classes was estimated using the Bayesian mixing model Stable Isotope Analysis in R (SIAR) (Parnell et al., 2010). In these models, we used data of main prey obtained in stomach contents by Sardiña and Lopez Cazorla (2005) adjacent to the study area. Isotope values of prey published for SWACE were used in the models, which included one species of mysid Neomysis americana (Smith 1873) and the sergestid Peisos petrunkevitchi (Burkenroad 1945) (Ciancio et al., 2008; Botto et al., 2011). Isotope values of Engraulis anchoita from the study area (Bahía Blanca estuary) were determined in this study.

A trophic discrimination factor (TDF) of $1.0 \%$ and $3.4 \%$ was applied for $\delta^{13} \mathrm{C}$ and $\delta^{15} \mathrm{~N}$, respectively, in order to compare prey and predator isotope values (DeNiro and Epstein, 1978, 1981; Post, 2002). Results were described as range percentage ( $\%$ ) with the $95 \%$ credibility interval (CI95). 


\section{Results}

Fifty-one individuals of Cynoscion guatucupa between 9.0 and $34.0 \mathrm{~cm}$ of TL $($ mean \pm S.D $=21.2 \pm 7.0 \mathrm{~cm}$ ) were analyzed. Isotope results ranged from $-18.0 \%$ to $-16.2 \%$ (mean \pm S.D $=-16.9 \pm 0.5 \%$ ) in $\delta^{13} \mathrm{C}$ and from $16.1 \%$ to $18.5 \%$ (mean \pm S.D $=17.6 \pm 0.5 \%$ o in $\delta^{15} \mathrm{~N}$ (Table 1$)$. We found no differences in

both $\delta^{13} \mathrm{C}$ and $\delta^{15} \mathrm{~N}$ with the sampling location $(\mathrm{N} v s$. $\mathrm{MH}, \mathrm{ANOVA} \delta^{15} \mathrm{~N}: \mathrm{F}=3.33, p=0.089$ and $\delta^{13} \mathrm{C}: \mathrm{F}=0.09$, $p=0.77)$. A significant positive correlation was found between both isotope values and TL of the animals $\left(\delta^{13} \mathrm{C}: \mathrm{R}^{2}=0.39, n=51,95 \% \mathrm{CI}=-18.05\right.$ to -17.41 , $p<0.0001$, and $\delta^{15} \mathrm{~N}: \mathrm{R}^{2}=0.51, n=51,95 \% \mathrm{CI}=16.02$ to $16.72, p<0.0001$ ) (Figure 2).

The cluster analysis defined three groups of size classes of C. guatucupa with significant differences in isotope composition among them (Figure 3a, SIMPROF test). These groups were delineated at a $75 \%$ similarity level in the cluster analysis. The resulting MDS plots indicated an excellent representation (stress $=0$ ) and gave the same picture as the dendrogram (Figure $3 b$ ). The coincidence in the results using these two methods strongly supported the size classes defined. Thus, the size classes were defined as follows: 1) $9.25-10.25 \mathrm{~cm}, 2) 13.25-17.25 \mathrm{~cm}$ and 3) $17.75-34.25 \mathrm{~cm}$.

We found two peculiar individuals, with $\mathrm{TL}=22.25 \mathrm{~cm}$ and $12.75 \mathrm{~cm}$, which were grouped in different size classes to which corresponded. The first one was grouped with smaller individuals than their own size class, and the second one with bigger individuals. Despite that size related dietary shifts is expected to occur in many species, such as C. guatucupa, this may not occur at strictly the same TL for all the individuals within species. These individuals are probably feeding on prey that has higher/lower values than the main prey of their respective group.

Significant differences were found in both isotope values amongst three size classes (Table 2) (ANOVA: $F_{2,48}=16.2, p<0.0001$ for $\delta^{13} \mathrm{C} ; F_{2,48}=22.5$, $p<0.0001$ for $\left.\delta^{15} \mathrm{~N}\right)$. Specifically, size class 3 had significantly higher $\delta^{13} \mathrm{C}$ values than size class 2 , with a $\Delta^{13} \mathrm{C}=0.7 \%$. In $\delta^{15} \mathrm{~N}$, size class 3 had significantly higher values than size class 2 and this higher than size class 1 , with a $\Delta^{15} \mathrm{~N}=1.5 \%$ between size classes (Figure 4, Figure 5).

The isotopic values of the main prey of $C$. guatucupa ranged between $-20.2 \%$ and $-18.0 \%$ in $\delta^{13} \mathrm{C}$ and between $12.0 \%$ to $14.8 \%$ o in $\delta^{15} \mathrm{~N}$ (Table 1 ). The $\delta^{13} \mathrm{C}$ and $\delta^{15} \mathrm{~N}$ values for crustaceans increase from miscidaceans to the sergestid $P$. petrunkevitchi whilst the E. anchoita presented

Table 1. Mean $\delta^{13} \mathrm{C}$ and $\delta^{15} \mathrm{~N}$ values of muscle of striped weakfish Cynoscion guatucupa and its prey species from the Southwest Atlantic Coastal Ecosystem.

\begin{tabular}{ccccccc}
\hline Species & $\begin{array}{c}\text { Common } \\
\text { name }\end{array}$ & $\mathbf{n}$ & $\mathbf{T L}$ & $\boldsymbol{\delta}^{\mathbf{1 3}} \mathbf{C}$ (SD) & $\boldsymbol{\delta}^{\mathbf{1 5} \mathbf{N}(\mathbf{S D})}$ & Reference \\
\hline $\begin{array}{c}\text { Cynoscion } \\
\text { guatucupa }\end{array}$ & $\begin{array}{c}\text { striped } \\
\text { weakfish }\end{array}$ & 51 & 21.2 & $-16.9(0.5)$ & $17.6(0.5)$ & This study \\
\hline $\begin{array}{c}\text { Neomysis } \\
\text { americana }\end{array}$ & mysids & 2 & - & $-20.2(0.2)$ & $12.0(0.2)$ & $\begin{array}{c}\text { Botto et al. } \\
(2011)\end{array}$ \\
\hline $\begin{array}{c}\text { Peisos } \\
\text { petrunkevitchi }\end{array}$ & $\begin{array}{c}\text { patagonian } \\
\text { shrimp }\end{array}$ & 3 & 3.7 & $-18.0(0.2)$ & $13.0(0.4)$ & $\begin{array}{c}\text { Ciancio et al. } \\
(2008)\end{array}$ \\
\hline $\begin{array}{c}\text { Engraulis } \\
\text { anchoita }\end{array}$ & anchovy & 2 & 10.8 & $-18.4(0.3)$ & $14.8(0.2)$ & This study \\
\hline
\end{tabular}

$\mathrm{n}=$ number of specimens; Mean TL $(\mathrm{cm})=$ total body length; $\mathrm{SD}=$ standard deviation.
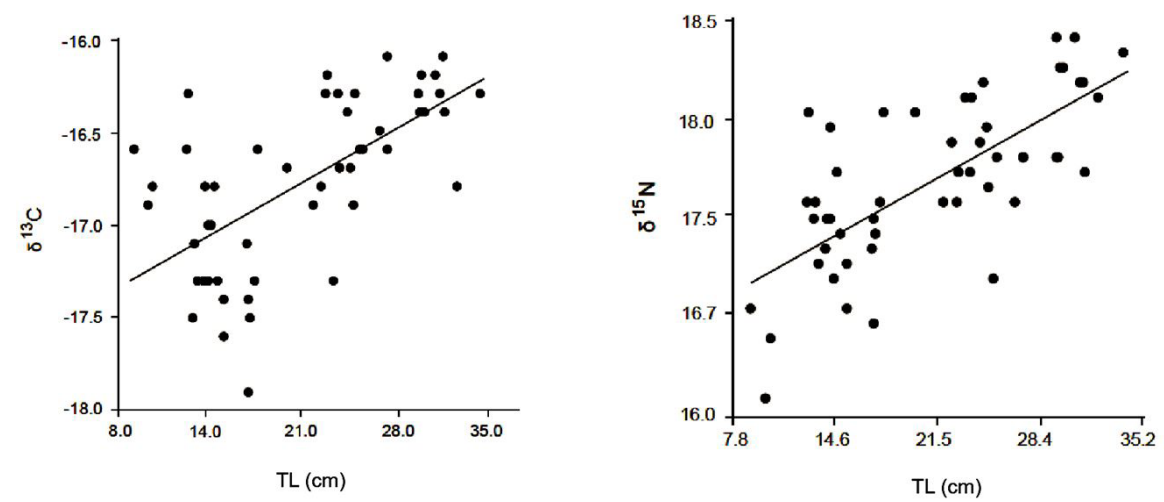

Figure 2. Isotopic correlation of $\delta^{13} \mathrm{C}$ and $\delta^{15} \mathrm{~N}$ values with size (TL, cm) determined in muscle of striped weakfish Cynoscion guatucupa from the south SWACE. 
the highest values in $\delta^{15} \mathrm{~N}$ (Figure 5). All the size classes of $C$. guatucupa exhibited intermediate values of $\delta^{15} \mathrm{~N}$ between the crustacean $P$. petrunkevitchi and the fish E. anchoita (Table 1, Table 2; Figure 5).

The stable isotope mixing model (SIAR) clearly showed that the relative consumption of each prey species changed as a function of the size class (Figure 6). The consumption of miscidacean ( $N$. americana) decreases significantly relative to larger $C$. guatucupa. The same decline occurred with the sergestid ( $P$. petrunkevitchi) unlike the pelagic fish $E$. anchoita, which showed the opposite behavior, increasing progressively their contribution in each size class as animal grow. The major contribution to the diet in size class 1 was $P$. petrunkevitchi followed by miscidacean and the anchovy but in a low proportion. Then the sergestid and the anchovy were the most important prey in size class 2 with similar contributions. However, in size class 3 , the anchovy seemed to be the most important prey in the diet with a poor contribution of the sergestid (Figure 6). a)

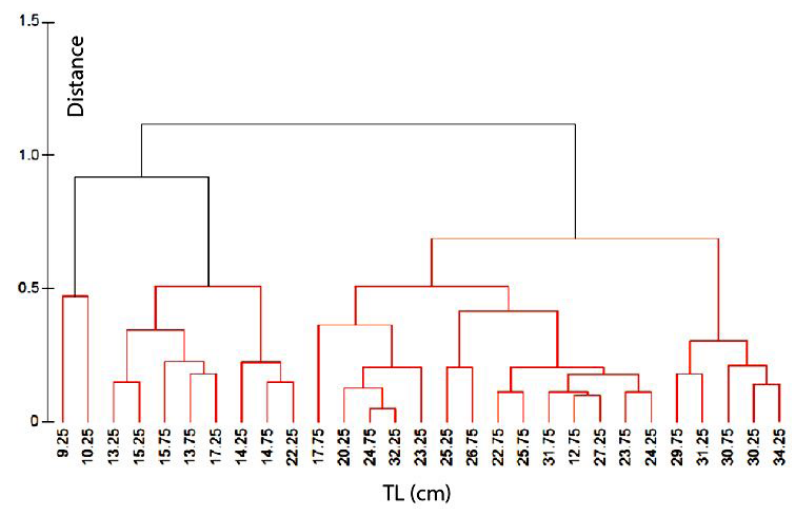

b)

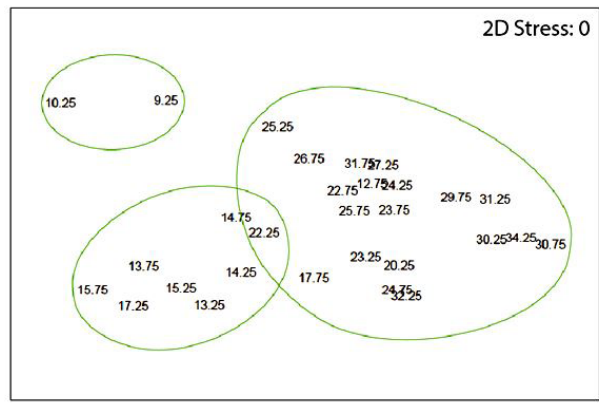

Figure 3. (a) Cluster Analysis with SIMPROF test and (b) Multi-dimensional Scaling configuration (0.7 distance, MDS, stress $=0$ ) showing similarities in isotope compositions and grouping in different size classes (Class 1 to 3 ) of striped weakfish Cynoscion guatucupa from the south SWACE. The red branches indicate that the SIMPORF test cannot find statistical evidence for any-substructure within theses.

Table 2. Mean $\delta^{13} \mathrm{C}$ and $\delta^{15} \mathrm{~N}$ values of muscle of striped weakfish Cynoscion guatucupa at different size classes (1 to 3$)$ from the Southwest Atlantic Coastal Ecosystem.

\begin{tabular}{cccccc}
\hline Size class & Mean TL & Size range & $\mathbf{n}$ & $\boldsymbol{\delta}^{\mathbf{1 3}} \mathbf{C}(\mathbf{S D})$ & $\boldsymbol{\delta}^{\mathbf{1 5}} \mathbf{N}(\mathbf{S D})$ \\
\hline 1 & 9.80 & $9.25-10.25$ & 3 & $-16.9(0.2)$ & $16.4(0.3)$ \\
2 & 14.80 & $13.25-17.25$ & 18 & $-17.3(0.4)$ & $17.2(0.4)$ \\
3 & 26.20 & $17.75-34.25$ & 30 & $-16.6(0.3)$ & $17.9(0.4)$ \\
\hline
\end{tabular}

Mean TL $(\mathrm{cm})$, range size $(\mathrm{cm}), \mathrm{n}=$ number of specimens, $\delta^{13} \mathrm{C}, \delta^{15} \mathrm{~N}$ and $\mathrm{SD}=$ standard deviation.
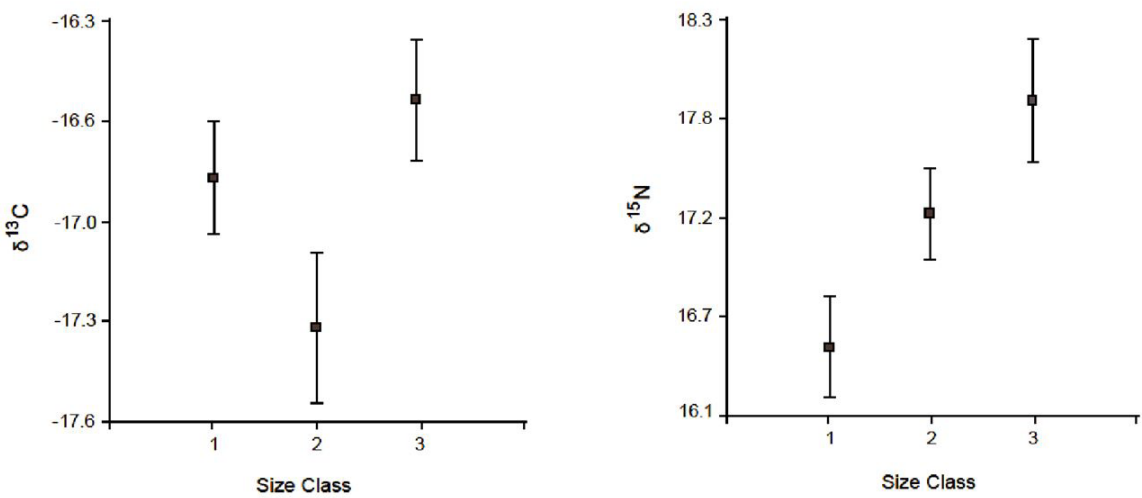

Figure 4. Mean $\delta^{13} \mathrm{C}$ and $\delta^{15} \mathrm{~N}$ values of muscle of striped weakfish Cynoscion guatucupa at different size classes (Class 1 to 3 ) from the south SWACE. 


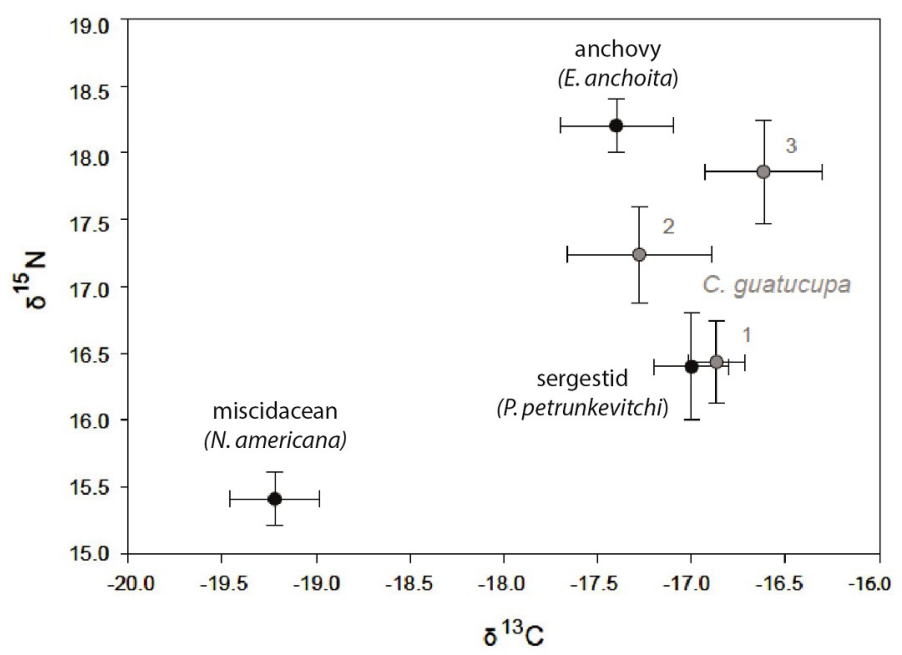

Figure 5. Biplot of $\delta^{13} \mathrm{C}$ and $\delta^{15} \mathrm{~N}$ of muscle of striped weakfish Cynoscion guatucupa (grey circles) at different size classes (Class 1 to 3 ) and its main prey (black circles) from the south SWACE. Prey isotope values were corrected for trophic discrimination $\left(+1.0 \%\right.$ and $+3.4 \%$ for $\delta^{13} \mathrm{C}$ and $\delta^{15} \mathrm{~N}$, respectively).

\section{Size Class}

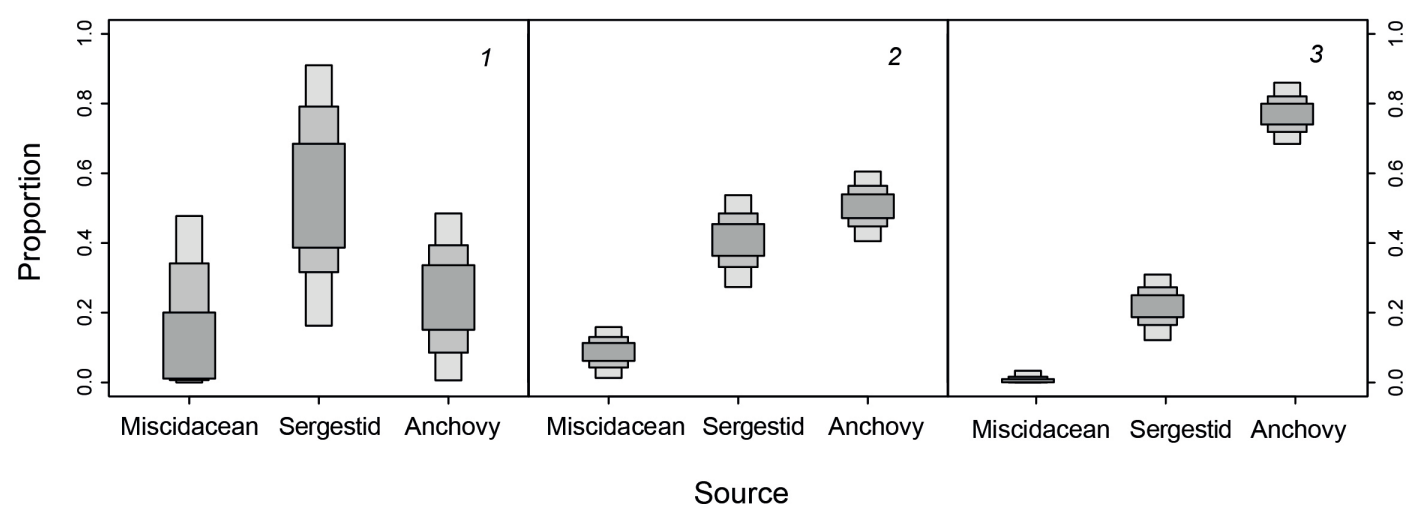

Figure 6. Relative contribution to the diet of main prey sources in each size class (Class 1 to 3) of striped weakfish Cynoscion guatucupa as modeled by SIAR. Results are reported as 95, 75 and $25 \%$ credibility intervals (box-plot). Prey species analyzed were miscidacean (Neomysis americana), sergestid (Peisos petrunkevitchi) and anchovy (Engraulis anchoita).

\section{Discussion}

Previous studies on the feeding habits by conventional methods in SWACE waters have provided general information on the diet of Cynoscion guatucupa (Cordo, 1986; Lopez Cazorla, 1996; Sardiña and Lopez Cazorla, 2005; García, 2007; Blasina et al., 2015). Ontogenetic shifts in the diet of this species were reported in southern Buenos Aires coast (García, 2007) and in estuarial areas (Sardiña and Lopez Cazorla, 2005; Blasina et al., 2015), where smaller individuals fed mainly on crustaceans whilst adults on pelagic fish.

The present study shows that stable isotope analysis of C. guatucupa from SWACE was in agreement with previous information provided through conventional methods.

The stable isotopes analysis showed that the relative consumption of each prey species changed as a function of animal size. This conclusion was mainly supported by 1) a positive correlation between isotope values and size; 2) the three groups of size classes defined by the Cluster analysis, which identified two diet shifts; 3 ) the validation of the three groups of size classes by the MDS; and 4) the differences in the relative consumption of distinct prey species in each size class detected by SIAR.

Significant differences were found in both isotope values amongst the three size classes in the study area. Although Botto et al. (2011) did not analyzed differences in isotope values between distinct sizes classes, similar results were found in C. guatucupa from the Rio de la Plata Estuary as adults had significant higher $\delta^{15} \mathrm{~N}$ values than juveniles but not differences in $\delta^{13} \mathrm{C}$ were observed.

The increment in the isotope composition of C. guatucupa with size would be associated with the consumption of 
different prey type with higher trophic levels. Small Cynoscion guatucupa prefer little crustaceans such as miscidacean, then consume sergestids (bigger crustacean) and as animals grow, they progressively incorporate fish (E. anchoita) to the diet (Sardiña and Lopez Cazorla, 2005; García, 2007).

The first shift in the diet observed through stable isotopes was at $\sim 13 \mathrm{~cm}$ in length and it could be explained by the increment in the consumption of E. anchoita and the decrease in the sergestid as shown by the SIAR analysis. In accordance with these results, previous analysis of stomach content also found an increment in the consumption of $E$. anchoita at approximately the same size (Sardiña and Lopez Cazorla, 2005; García, 2007). The second shift at $\sim 17 \mathrm{~cm}$ of TL was associated with the absence of miscidacean in the diet and a high difference between the contributions of sergestid and the anchovy between size classes.

Stomach contents showed that trophic ontogenetic shifts involve not only a change in the species consumed, as mentioned above, but also an increase in the food intake, in both number, biomass and the average size of prey consumed (Sardiña and Lopez Cazorla, 2005). Precisely, a progressive increase in the proportion of contribution of $E$. anchoita from $\sim \% 0.3, \sim \% 0.5$ and $\sim \% 0.8$ in each size class (1, 2 and 3; respectively) was corroborated by SIAR, being the most important prey in largest sizes. A similar result was found by Blasina et al. (2015) in Mar Chiquita Lagoon, Buenos Aires coast, where teleosts was consumed by smaller individuals $(<28.0 \mathrm{~cm}$ of TL) in a low proportion $(\leq 11 \%)$ of the total diet, while in the largest animals the relative contribution of that group increased significantly, being close to $100 \%$.

The analysis of the isotope values based on sampling location showed no differences in both $\delta^{13} \mathrm{C}$ and $\delta^{15} \mathrm{~N}$ between Necochea and Monte Hermoso. However, statistical differences in isotope values were detected amongst size groups. These differences in carbon isotopes are only between size classes 2 with size class 3 . Size class 1 shows no significant differences probably due to the low number of individuals in that group. The differences in $\delta^{13} \mathrm{C}$ amongst size classes seem to be due to an age-class specific spatial distribution pattern found in the Argentinean and Uruguayan coast within the estuarine - marine gradient (Jaureguizar et al., 2006). They defined age-class areas throughout the estuarine marine gradient in association with environmental variables. Size classes 1 and 2 (aged $0+$ and $1+$ ) mainly occurred in shallower, warmer and less saline water than intermediate age classes such as size class 3 (ages 2+ and 3+) (Jaureguizar et al., 2006; Ruarte and Saez, 2008). Then, carbon differences indicated different diet sources between these size classes.

These results are congruent with size-based marine food webs (Davis et al., 2012) and also consistent with the optimal foraging theory, which establishes that as fish grow, the preys they consumed are increasingly larger, optimizing the cost - benefit energetically (Gerking, 1994). Animals generally feed on prey smaller than themselves, and as they growth, size-related dietary shifts are expected to occur. In this case, isotopic evidence of a diet shift was possible to document, since this species consumes different prey types at different sizes, with remarkably distinctive isotope values.

This work provides new isotopic data regarding sizes on the juvenile stage of $C$. guatucupa, which plays an important role as major consumer of zooplankton in the area (Sardiña and Lopez Cazorla, 2005). It was possible to corroborate based on long-term methodology (isotopes composition), the ontogenetic differences previously observed in diet of this species by conventional methods (Sardiña and Lopez Cazorla, 2005; García, 2007) and concluded that large and small C. guatucupa from SWACE remain specialized but feeding on different prey at different trophic levels and in different areas. It was allowed, the detection of three size classes with isotope similarities, identifying sizes with important shifts in diet.

This work highlights the importance of accounting for size of fish when performing isotopic ecology models. We provide mean values of isotopic composition for different size classes of C. guatucupa that could be used as input data in future studies of food webs since this species represent an important prey of different marine mammals and seabirds from the area (Petracci et al., 2004; Suarez et al., 2005; Paso Viola et al., 2014). These results also contribute to the study of the diet of the striped weakfish as reinforced previous classical studies of diet based on analysis of stomach content, providing valuable information on the variation in the isotopic composition in response to dietary shifts of one of the most important fishery resources from the Southwest Atlantic Ocean.

\section{References}

AUBONE, A., RUARTE, C. and DI MARCO, E., 2006. Un modelo matricial estructurado por estadios de tallas para la pescadilla de red (Cynoscion guatucupa) al sur de los $39^{\circ} \mathrm{S}$, 1995-2005. In: INSTITUTO NACIONAL DE INVESTIGACIÓN Y DESARROLLO PESQUERO - INIDEP, ed. Informe de asesoramiento y transferencia. Buenos Aires: INIDEP, pp. 19-16.

BLASINA, G.E., LOPEZ CAZORLA, A.C. and DÍAZ DE ASTARLOA, J.M., 2015. Possible predation by the striped weakfish Cynoscion guatucupa on estuary-associated fishes in an Argentinian coastal lagoon. Marine Biology Research, vol. 11, no. 6, pp. 613-623. http://dx.doi.org/10.1080/17451000.2014.973417.

BOTTO, F., GAITÁN, E., MIANZAN, H., ACHA, M., GIBERTO, D., SCHIARITI, A. and IRIBARNE, O., 2011. Origin of resources and trophic pathways in a large SW Atlantic estuary: an evaluation using stable isotopes. Estuarine, Coastal and Shelf Science, vol. 92, no. 1, pp. 70-77. http://dx.doi.org/10.1016/j.ecss.2010.12.014.

BOWEN, W.D., 2000. Reconstruction of pinniped diets: accouting for complete digestion of otoliths and cephalopod peaks. Canadian Journal of Fisheries and Aquatic Sciences, vol. 75, no. 5, pp. 898-905. http://dx.doi.org/10.1139/f00-032.

CIANCIO, J.E., PASCUAL, M.A., BOTTO, F., FRERE, E. and IRIBARNE, O., 2008. Trophic relationships exotic anadromous salmonids in southern Patagonian Shelf as inferred from stable 
isotopes. Limnology and Oceanography, vol. 53, no. 2, pp. 788798. http://dx.doi.org/10.4319/1o.2008.53.2.0788.

CLARKE, K.R., SOMERFIELD, P.J. and GORLEY, R.N., 2008. Testing null hypotheses in exploratory community analyses: similarity profiles biota-environmental linkage. Journal of Experimental Marine Biology and Ecology, vol. 366, no. 1, pp. 56-69. http://dx.doi.org/10.1016/j.jembe.2008.07.009.

COPLEN, T.B., 2011. Guidelines and recommended terms for expression of stable isotope-ratio and gas-ratio measurement results. Rapid Communications in Mass Spectrometry, vol. 25, no. 17, pp. 2538-2560. PMid:21910288. http://dx.doi.org/10.1002/rcm.5129.

COPLEN, T.B., KROUSE, H.R. and BOHLKE, J.K., 1992. Reporting of nitrogen-isotope abundances. Pure and Applied Chemistry, vol. 6, pp. 907-908.

CORDO, H.D., 1986. Estudios biológicos sobre peces costeros con datos de campañas de investigación realizadas en 1981. III. La pescadilla de red (Cynoscion striatus). Publicación de la Comisión Técnica Mixta del Frente Marítimo, vol. 1, pp. 15-27.

COUSSEAU, M.B. and PERROTTA, R.G., 2000. Peces marinos de Argentina: biología, distribución, pesca. 2nd ed. Mar del Plata: Instituto Nacional de Investigación y Desarrollo Pesquero - INIDEP. 167 p.

COUSSEAU, M.B., COTRINA, C.P., CORDO, H.D. and BURGOS, G.E., 1986. Análisis de datos biológicos de corvina rubia (Micropogonias furnieri) y pescadilla de red (Cynoscion striatus) obtenidos en dos campañas del año 1983. Publicación de la Comisión Técnica Mixta del Frente Marítimo, vol. 1, pp. 319-332.

DAVIS, A.M., BLANCHETTE, M.L., PUSEY, B.J., JARDINE, T.D. and PEARSON, R.G., 2012. Gut content and stable isotope analyses provide complementary understanding of ontogenetic dietary shifts and trophic relationships among fishes in a tropical river. Freshwater Biology, vol. 57, no. 10, pp. 2156-2172. http:// dx.doi.org/10.1111/j.1365-2427.2012.02858.x.

DENIRO, M.J. and EPSTEIN, S., 1978. Influence of diet on the distribution of carbon isotopes in animals. Geochimica et Cosmochimica Acta, vol. 42, no. 5, pp. 495-506. http://dx.doi. org/10.1016/0016-7037(78)90199-0.

DENIRO, M.J. and EPSTEIN, S., 1981. Influence of diet on the distribution of nitrogen isotopes in animals. Geochimica et Cosmochimica Acta, vol. 45, no. 3, pp. 341-351. http://dx.doi. org/10.1016/0016-7037(81)90244-1.

DI RIENZO, J.A., CASANOVES, F., BALZARINI, M.G., GONZALEZ, L., TABLADA, M. and ROBLEDO, C.W., 2011 [viewed 26 January 2016]. InfoStat software estadístico [software]. Córdoba: Universidad Nacional de Córdoba. Available from: http://www.infostat.com.ar

ELIAS, I., CAROZZA, C., DI GIACOMO, E.E., ISLA, M.S., ORENSANZ, J.M., PARMA, A.M., PEREIRO, R.C., PERIER, M.R., PERROTTA, R.G., RE, M.E. and RUARTE, C., 2011. Coastal fisheries of Argentina. In: S. SALAS, R. CHUENPAGDEE, A. CHARLES and J.C. SEIJO, eds. Coastal fisheries of Latin America and the Caribbean. Rome: FAO, pp. 13-48. FAO Fisheries and Aquaculture Technical Paper, no. 544.

GALVAN, D.E., SWEETING, C.J. and REID, W.D.K., 2010. Power of stable isotope techniques to detect size-based feeding in marine fishes. Marine Ecology Progress Series, vol. 407, pp. 271-278. http://dx.doi.org/10.3354/meps08528.
GARCÍA, S., 2007 [viewed 26 January 2016]. Ecología trófica de la pescadilla de red, Cynoscion guatucupa, en el sector costero argentino-uruguayo $\left(34^{\circ}-41^{\circ} \mathrm{S}\right)$ [online]. Mar del Plata: Facultad Ciencias Exactas y Naturales Universidad Nacional de Mar del Plata, 38 p. Tesis de Licenciatura. Available from: http://hdl. handle.net $/ 1834 / 3583$.

GERKING, D.S., 1994. Feeding ecology of fish. California: Academic Press. 416 p.

GIBERTO, D.A., 2008. Estructura de la Comunidad Bentónica y Ecología Trófica de Scienidae (Pisces: Osteichthyes) en el Estuario del Río de la Plata. Argentina: Universidad Nacional del Comahue. 224 p. Doctoral Thesis.

HAIMOVICI, M., 1998. Present state and perspectives for the southern Brazil shelf demersal fisheries. Fisheries Management and Ecology, vol. 5, no. 4, pp. 277-289. http://dx.doi.org/10.1046/ j.1365-2400.1998.540277.x.

HOBSON, K.A. and CLARK, R.G., 1992. Assessing avian diets using stable isotopes I: turnover of ${ }^{13} \mathrm{C}$ in tissues. The Condor, vol. 94, no. 1, pp. 181-188. http://dx.doi.org/10.2307/1368807.

JAUREGUIZAR, A.J., RUARTE, C. and GUERRERO, R., 2006. Distribution of age-classes of striped weakfish (Cynoscion guatucupa) along an estuarine-marine gradient: correlations with the environmental parameters. Estuarine, Coastal and Shelf Science, vol. 67, no. 1-2, pp. 82-92. http://dx.doi.org/10.1016/j. ecss.2005.10.014.

LLOMPART, F.M., COLAUTTI, D.C. and BAIGUN, C.R.M., 2011. Assessment of a major shore-based marine recreational fishery in the southwest Atlantic, Argentina. New Zealand Journal of Marine and Freshwater Research, vol. 46, no. 1, pp. 57-70. http://dx.doi.org/10.1080/00288330.2011.595420.

LOGAN, J.M., JARDINE, T.D., MILLER, T.J., BUNN, S.E., CUNJAK, R.A. and LUTCAVAGE, M.E., 2008. Lipid corrections in carbon and nitrogen stable isotope analyses: comparison of chemical extraction and modelling methods. Journal of Animal Ecology, vol. 77, no. 4, pp. 838-846. PMid:18489570. http:// dx.doi.org/10.1111/j.1365-2656.2008.01394.x.

LOPEZ CAZORLA, A., 1996. The food of Cynoscion striatus (Cuvier) (Pisces: Siaenidae) in the Bahía Blanca area, Argentina. Fisheries Research, vol. 28, no. 4, pp. 371-379. http://dx.doi. org/10.1016/S0165-7836(96)00515-2.

LOPEZ CAZORLA, A., MOLINA, J.M. and RUARTE, C., 2014. The artisanal fishery of Cynoscion guatucupa in Argentina: Exploring the possible causes of the collapse in Bahía Blanca estuary. Journal of Sea Research, vol. 88, pp. 29-35. http://dx.doi. org/10.1016/j.seares.2013.12.016.

LUNDVALL, D., SVANBACK, R., PERSSON, L. and BYSTROM, P., 1999. Size-dependent predation in piscivores: interactions between predator foraging and prey avoidance abilities. Canadian Journal of Fisheries and Aquatic Sciences, vol. 56, no. 7, pp. 1285-1292. http://dx.doi.org/10.1139/f99-058.

MACCHI, G.J. and ACHA, M.E., 1998. Aspectos reproductivos de las principales especies de peces en la Zona Común de Pesca Argentino-Uruguaya y en El Rincón - Noviembre 1994. In: C.A. LASTA, ed. Resultados de una campaña de evaluación de recursos demersales costeros de la provincia de Buenos Aires y del Litoral Uruguayo - Noviembre 1994. Buenos Aires: INIDEP, pp. 67-89. INIDEP Informe Técnico, no. 21.

MICHENER, R.H. and KAUFMAN, L., 2007. Stable isotope ratios as tracers in marine food webs: an update. In: R. MICHENER, 
K. LAJTHA, eds. Stable isotopes in ecology and Environmental Science. Malden: Blackwell Publishing, pp. 238-282.

NEWSOME, S.D., ETNIER, M.A., MONSON, D.H. and FOGEL, M.L., 2009. Retrospective characterization of ontogenetic shifts in killer whale diets via $\delta^{13} \mathrm{C}$ and $\delta^{15} \mathrm{~N}$ analysis of teeth. Marine Ecology Progress Series, vol. 374, pp. 229-242. http://dx.doi. org/10.3354/meps07747.

PARNELL, A.C., INGER, R., BEARHOP, S. and JACKSON, A.L., 2010. Source partitioning using stable isotopes: coping with too much variation. PLoS One, vol. 5, no. 3, p. e9672. PMid:20300637. http://dx.doi.org/10.1371/journal.pone.0009672.

PASO VIOLA, M.N., DENUNCIO, P., NEGRI, M.F., RODRIGUEZ, D., BASTIDA, R. and CAPPOZZO, H.L., 2014. Diet Composition of franciscana dolphin, Pontoporia blainvillei, from southern Buenos Aires, Argentina and its interaction with fisheries. Revista de Biología Marina y Oceanografia, vol. 49, no. 2, pp. 393-400. http://dx.doi.org/10.4067/S0718-19572014000200019.

PERROTTA, R.G. and RUARTE, C.O., 2009. Analysis of the use of catch per unit of effort as an annual abundance index for stripped weakfish (Cynoscion guatucupa) period 1992-2004. Buenos Aires: INIDEP, pp. 1-13. INIDEP Informe Técnico, no. 70.

PETRACCI, P.F., LA SALA, L.F., AGUERRE, G., PEREZ, C.H., ACOSTA, N., SOTELO, M. and PAMPARANA, C., 2004. Dieta de la gaviota cocinera (Larus dominicanus) durante el período reproductivo en el estuario de Bahía Blanca, Buenos Aires, Argentina. El Hornero, vol. 19, no. 1, pp. 23-28.

PHILLIPS, D.L., 2001. Mixing models in analyses of diet using multiple stable isotopes: a critique. Oecologia, vol. 127, no. 2, pp. 166-170. PMid:24577645. http://dx.doi.org/10.1007/ s004420000571.

POST, D.M., 2002. Using stable isotopes to estimate trophic position: models, methods, and assumptions. Ecology, vol. 83, no. 3, pp. 703-718. http://dx.doi.org/10.1890/0012-9658(2002)083[0703:US ITET]2.0.CO;2.

POST, D.M., LAYMAN, C.A., ARRINGTON, D.A., TAKIMOTO, G., QUATTROCHI, J. and MONTANA, C.G., 2007. Getting to the fat of the matter: models, methods and assumptions for dealing with lipids in stable isotope analyses. Oecologia, vol. 152, no. 1, pp. 179-189. PMid:17225157. http://dx.doi.org/10.1007/ s00442-006-0630-x.

RUARTE, C. and AUBONE, A., 2008. Compendio de las evaluaciones de pescadilla de red en el período 2001-2007. Recomendaciones de manejo para el año 2008. INIDEP Informe Técnico, vol. 30, pp. 1-11.

RUARTE, C. and SAEZ, M.B., 2008. Estudio preliminar sobre la estructura de edades y el crecimiento de la pescadilla de red (Cynoscion guatucupa, Sciaenidae) en el área sur de la provincia de buenos aires. Revista de Investigación y Desarrollo Pesquero, vol. 19 , pp. $37-44$

SARDIÑA, P. and LOPEZ CAZORLA, A., 2005. Feeding habits of the juvenile striped weakfish of Cynoscion guatucupa (Cuvier 1830) in Bahía Blanca estuary (Argentina): seasonal and ontogenetic changes. Hydrobiologia, vol. 532, no. 1-3, pp. 23-38. http://dx.doi.org/10.1007/s10750-004-8769-0.

SCHARF, F.S., JUANES, F. and ROUNTREE, R.A., 2000. Predator size-prey size relationships of marine fish predators: interspecific variation and effects of ontogeny and body size on trophic-niche breadth. Marine Ecology Progress Series, vol. 208, pp. 229-248. http://dx.doi.org/10.3354/meps208229.

SHELDON, R.W., SUTCLIFFE JUNIOR, W.H. and PARANJAPE, M.A., 1977. Structure of pelagic food chain and relationship between plankton and fish production. Journal of the Fisheries Board of Canada, vol. 34, no. 12, pp. 2344-2353. http://dx.doi. org/10.1139/f77-314.

SUAREZ, A.A., SANFELICE, D., CASSINI, M.H. and CAPPOZZO, H.L., 2005. Composition and seasonal variation in the diet of the South American sea lion (Otaria flavescens) from Quequén, Argentina. The Latin American Journal of Aquatic Mammals, vol. 4, no. 2, pp. 163-174. http://dx.doi.org/10.5597/lajam00079.

VIEIRA, P.C. and HAIMOVICI, M., 1997. Reprodução da pescada olhuda Cynoscion guatucupa, sin. c. striatus (Sciaenidae, Teleosteii) no sul do Brasil. Atlantica, vol. 19, pp. 133-144. 